\title{
Regulation of Leydig cell steroidogenesis by extracellular signal-regulated kinase 1/2: role of protein kinase $A$ and protein kinase C signaling
}

\author{
Pulak R Manna*, Youngah Jo* and Douglas M Stocco \\ Department of Cell Biology and Biochemistry, Texas Tech University Health Sciences Center, Lubbock, Texas 79430, USA \\ (Requests for offprints should be addressed to D M Stocco; Email: doug.stocco@ttuhsc.edu) \\ *(P R Manna and Y Jo contributed equally to this work)
}

\begin{abstract}
The steroidogenic acute regulatory (StAR) protein plays a central role in the regulation of steroid biosynthesis. While steroidogenesis is influenced by many processes, their modes of actions, in a few cases, remain obscure. In this study, we explored the mechanism of action of one such signaling pathway, the extracellular signal-regulated kinase $1 / 2$ (ERK1/2), in regulating StAR expression and steroidogenesis in conjunction with the protein kinase $\mathrm{A}(\mathrm{PKA})$ and protein kinase C (PKC) pathways. Using MA-10 mouse Leydig tumor cells, we demonstrate that the activation of PKC and PKA signaling, by phorbol-12-myristate-13-acetate (PMA) and dibutyryl cAMP (dbcAMP)/human chorionic gonadotropin (hCG) respectively, was able to phosphorylate ERK1/2, an event markedly decreased by an upstream kinase inhibitor, U0126. Treatment with PMA enhanced StAR protein expression (associated with a slight increase in progesterone synthesis) but not its phosphorylation (PStAR), which, in contrast, coordinately increased in response to dbcAMP/hCG. Inhibition of ERK1/2 activity by U0126
\end{abstract}

decreased PMA-treated StAR expression but increased dbcAMP/hCG-mediated StAR and P-StAR; however, progesterone levels were attenuated. U0126 was found to affect StAR expression and steroidogenesis both at the transcriptional and translational levels. Further studies demonstrated that the effect of U0126 on PMA- and $\mathrm{dbcAMP} / \mathrm{hCG}$-mediated StAR expression and steroid synthesis was tightly correlated with the expression of dosage-sensitive sex reversal, adrenal hypoplasia congenita, critical region on the $\mathrm{X}$ chromosome, gene $1(D A X-1)$ and scavenger receptor class $\mathrm{B}$ type 1 (SR-B1). In fact, both DAX-1 and SR-B1 appear to play important roles in hormone-regulated steroidogenesis. These findings clearly demonstrate that the ERK1/2 signaling cascade involved in regulating StAR expression and steroid synthesis is mediated by multiple factors and pathways and is stimulus specific in mouse Leydig cells.

Journal of Endocrinology (2007) 193, 53-63

\section{Introduction}

Steroidogenesis in Leydig cells is predominantly mediated through the interaction of luteinizing hormone (LH)/human chorionic gonadotropin (hCG) with its specific receptor, which results in several intracellular modifications including the activation of cAMP-dependent protein kinase A (PKA) and phosphorylation of proteins (Cooke et al. 1992, Saez 1994, Ascoli et al. 2002, Stocco et al. 2005). The steroidogenic acute regulatory (StAR) protein regulates a key step in steroid biosynthesis, i.e. the delivery of cholesterol from the outer to the inner mitochondrial membrane (Clark et al. 1994, Lin et al. 1995, Stocco \& Clark 1996). Compelling evidence regarding the crucial role of StAR in the regulation of steroid synthesis has been documented with both basic and clinical studies (Clark et al. 1994, Lin et al. 1995, Caron et al. 1997,
Hasegawa et al. 2000). Transcriptional or translational inhibition of StAR expression results in a dramatic decrease in steroid biosynthesis, whereas $\approx 10-15 \%$ of steroid synthesis appears to be mediated through StAR-independent mechanisms (Lin et al. 1995, Stocco \& Clark 1996, Clark et al. 1997, Manna et al. 2001). Two putative PKA phosphorylation sites have been identified in the mouse StAR protein at Ser56 and Ser194, and mutations (Ser $\rightarrow$ Ala) in these sites demonstrated the importance of Ser194 in the biological activity of StAR in steroid synthesis (Arakane et al. 1997).

Whereas the cAMP/PKA pathway is unquestionably the major signaling cascade for tropic hormone-induced StAR expression and steroidogenesis, PKC has also been shown to be involved in these processes (Jo et al. 2005, Stocco et al. 2005, Manna et al. 2006a, Renlund et al. 2006). We have recently reported that the PKC signaling pathway plays an 
integral role in regulating the steroidogenic response in Leydig cells. While PKC-dependent induction of steroid synthesis is low when compared with that observed with PKA signaling, it is capable of potentiating gonadotropin and/or cAMP-stimulated steroidogenic responsiveness (Jo et al. 2005, Stocco et al. 2005, Manna et al. 2006a).

DAX-1 (also called NrOb1 or Ahch), an orphan member of the nuclear hormone receptor superfamily of transcription factors, is expressed in the hypothalamic-pituitary-adrenal/ gonadal axis and has been demonstrated to have roles in the regulation of steroidogenesis (Zazopoulos et al. 1997, Lalli et al. 1998, Osman et al. 2002, Tajima et al. 2003, Jo \& Stocco 2004, Manna et al. 2006a) as well as in the gonadal development and function (Yu et al. 1998, Meeks et al. 2003a,b, Niakan \& McCabe 2005). Targeted disruption of DAX-1 in mice results in testicular dysgenesis, which is manifested by decreased testicular size and decreased spermatogenesis, impaired Sertoli and Leydig cell function, and infertility (Yu et al. 1998, Jeffs et al. 2001, Meeks et al. $2003 a, b)$. Another protein considered in the present studies was SR-B1, a high-density lipoprotein (HDL) receptor that binds various lipoprotein particles, facilitates HDL-derived cellular cholesterol influx, and thus replenishes cholesterol stores for steroid hormone biosynthesis (Ji et al. 1997, Azhar et al. 1998, Fidge 1999). In previous studies, both in vivo and in vitro approaches have demonstrated a striking correlation between the hormonal induction of SR-B1 expression (accompanied by enhanced lipid uptake from HDL) and steroid biosynthesis in steroidogenic cells (Landschulz et al. 1996, Rigotti et al. 1996, Azhar et al. 1998, Sun et al. 1999, Manna et al. 2006b).

The mitogen activated protein kinase (MAPK) signaling cascade has been implicated in the regulation of cell cycle progression, is used as a biochemical marker in evaluating mitogenic effects of a variety of stimuli, and is a point of convergence for diverse signaling pathways (Seger \& Krebs 1995, Lewis et al. 1998, Le \& Schimmer 2001, Manna et al. 2006b). Extracellular signal-regulated kinase 1/2 (ERK1/2), a member of the family of MAPKs, has been shown to be involved in StAR expression and steroid biosynthesis. However, its mode of action is poorly understood as a consequence of conflicting reports demonstrating stimulation, inhibition, or no effect in different steroidogenic cells (Gyles et al. 2001, Seger et al. 2001, Martinelle et al. 2004, Martinat et al. 2005, Tajima et al. 2005, Manna et al. 2006b). Despite the importance of the PKA and PKC signaling pathways in steroidogenesis, their precise roles in the regulation of MAPK/ERK-mediated steroidogenic responsiveness remain elusive. Utilizing MA-10 mouse Leydig tumor cells (that possess many characteristics of normal Leydig cells including low levels of LH receptors) as an experimental model, the present studies were aimed at elucidating these roles and demonstrated that ERK1/2 signaling has a variety of effects on the regulation of StAR expression and steroidogenesis in Leydig cells that are dependent on the specific experimental conditions and stimuli utilized.

\section{Materials and Methods}

\section{Reagents}

Phorbol-12-myristate-13-acetate (PMA), dibutyryl cyclic AMP (dbcAMP), hCG, and H89 were purchased from Sigma. GF-10923X (GFX) was obtained from AG Scientific (San Diego, CA, USA). U0126 and ERK1/2 antibody were purchased from Cell Signaling (Beverly, MA, USA). Phosphorylated ERK1/2 monoclonal antibody was obtained from Santa Cruz Biotechnology (Santa Cruz, CA, USA).

\section{Cell culture and treatments}

MA-10 mouse Leydig tumor cells (Ascoli 1981) were grown in Waymouth MB 752/1 medium supplemented with 15\% horse serum (Invitrogen) and antibiotics, as described previously (Manna et al. 2004a, Jo et al. 2005). Prior to experiments, cells were washed with $0.01 \mathrm{M}$ PBS and incubated with or without additives (stimulators, inhibitors, etc.), which were freshly prepared and applied to the cells. Media were collected from different treatment groups and the accumulation of progesterone (increased several hundredfold over basal in response to tropic hormone or cAMP analog in 4-6 h) was determined (Manna et al. 2002b, Rao et al. 2003, Jo et al. 2005, Manna et al. 2006b). Some caution should be taken in measuring progesterone as the sole product of steroidogenesis in MA-10 cells, as a previous study has demonstrated that additional steroid metabolites are also present in these cells (Rommerts et al. 2001). However, the levels of such metabolites are low when compared with progesterone production in MA-10 cells.

\section{Western blot analysis}

Following the experiments, cells were washed, homogenized in lysis buffer $(50 \mathrm{mM}$ Tris, $\mathrm{pH} \mathrm{7 \cdot 4,} 150 \mathrm{mM} \mathrm{NaCl}, 2 \mathrm{mM}$ phenylmethylsulfonyl fluoride, $2 \mu \mathrm{g} / \mathrm{ml}$ aprotinin, and $1 \%$ $\mathrm{NP}-40$ ), centrifuged at $12000 \mathrm{~g}$ for $10 \mathrm{~min}$, and the supernatant was assayed for total protein (Jo \& Stocco 2004, Manna et al. 2006b). Equal amounts of protein were loaded on 10\% SDS-PAGE gels and following electrophoresis were transferred to methanol-activated polyvinylidene difluoride membranes. Membranes were probed with specific antibodies that recognize phosphorylated (P)-ERK1/2, total ERK1/2, DAX-1 (Tamai et al. 1996; a gift from Dr Paolo Sassone-Corsi, University Louis Pasteur, Strasbourg, France), P-StAR (Manna et al. 2006b; a gift from Dr Steven R King, Baylor College of Medicine, Houston, TX, USA), and total StAR (Bose et al. 1999; a gift from Dr Walter L Miller, University of California, San Francisco, CA, USA). The antibody detecting P-StAR was generated against amino acids 190-199 of mouse StAR with phosphorylated Ser194. Horseradish peroxidase-conjugated secondary antibodies against rabbit, mouse, or goat IgG were used to recognize relevant primary antibodies. 
Immunodetection of different proteins was determined by chemiluminescence following exposure to X-ray film (Marsh Bio Products, Inc., Rochester, NY, USA), and the immunoblots were quantified using a computer-assisted image analyzer (Visage 2000, BioImage Corp., Ann Arbor, MI, USA). Expression of phosphorylated and total proteins was assessed using identically processed membranes; however, where appropriate, the same membranes were also analyzed by stripping and reprobing.

\section{Quantitative reverse transcription and PCR (RT-PCR)}

Total RNA was isolated from different treatment groups using Trizol reagent (Invitrogen). RT-PCR was run sequentially in the same assay tube using $2 \mu \mathrm{g}$ of total RNA, as described previously (Manna et al. 1999a, 2002b, 2004b). Isolation and amplification of StAR and SR-B1 cDNAs were carried out utilizing the following primer pairs: StAR sense, $5^{\prime}$-GACCTTGAAAGGCTCAGGAAGAAC-3' and StAR antisense, 5'-TAGCTGAAGATGGACAGACTTGC-3'; SR-B1 sense, 5'-CTCATCAAGCAGCAGGTGCTCAAGAA-3' and SR-B1 antisense, 5'-GGTGGGTAGACGGACCCGTTGGCAAACA-3'. The variation in RT-PCR efficiency was assessed using $\mathrm{L} 19$ ribosomal protein gene using the sense primer $5^{\prime}$-GAAATCGCCAATGCCAACTC- $3^{\prime}$ and the antisense primer $5^{\prime}$-TCTTAGACCTGCGAGCCTCA$3^{\prime}$. The cDNAs generated were further amplified by PCR using the primer pairs listed above. The parameters used were optimized to be in the exponential phase of the PCR. The molecular sizes of StAR, SR-B1, and L19 were determined on $1 \cdot 2 \%$ agarose gels. Gels were vacuum dried, exposed to X-ray film (Marsh Bio Products) for 1-3 h, and the resulting signals were quantified (Visage 2000). Integrated optical density (IOD) values of each StAR band were quantified and normalized with the corresponding L19 bands.

\section{Statistical analysis}

All experiments were repeated at least three times. Data were analyzed by either Student's $t$-test or ANOVA followed by Fisher's least significant difference tests using the StatView program (Abacus Concepts, Inc., Berkeley, CA, USA). Data were expressed as the mean \pm s.E.M. and the $P<0.05$ values were considered significant.

\section{Results}

Roles of the PKC and PKA pathways in ERK1/2 signaling and their relevance to $S t A R$ expression and progesterone synthesis

The mechanism of the ERK1/2 signaling cascade in the regulation of StAR expression and steroidogenesis was studied in MA-10 cells. Cells were treated with PMA and dbcAMP in order to activate the PKC and PKA pathways respectively, and phosphorylation and expression of ERK1/2 were determined. Phosphorylation of ERK1/2 (P-ERK1/2), following PMA treatment increased by $3 \mathrm{~min}$, was maximal between 10 and $120 \mathrm{~min}$ ( $\sim 4 \cdot 6$-fold) and decreased by
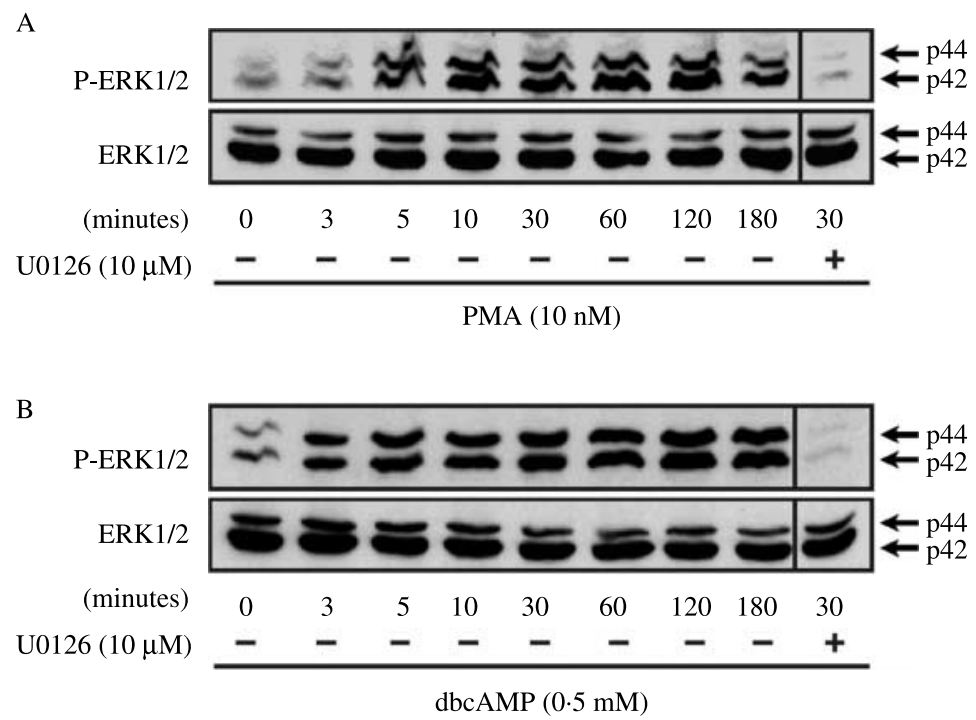

Figure 1 Effects of PMA and dbcAMP on phosphorylation and expression of ERK1/2 in MA-10 cells. Cells were treated with $10 \mathrm{nM}$ PMA (A) and $0.5 \mathrm{mM}$ dbcAMP (B) for different time periods (0-180 min). P-ERK1/2 and ERK1/2 in total cell lysates (22-25 $\mu \mathrm{g}$ protein) were determined by western blot analysis. Cells were also pretreated with the ERK1/2 inhibitor, U0126 $(10 \mu \mathrm{M})$, for 30 min treated with PMA and dbcAMP for an additional $30 \mathrm{~min}$ as indicated, and P-ERK1/2 and ERK1/2 were determined. Immunoblots are representative of three independent experiments. 
$180 \mathrm{~min}$, the longest time tested (Fig. 1A). Also, dbcAMP $(0.5 \mathrm{mM})$ resulted in an increase in P-ERK1/2 by $3 \mathrm{~min}$ $(P<0 \cdot 05)$ and a $5 \cdot 8 \pm 0 \cdot 9$-fold increase by $30 \mathrm{~min}$, an induction that was sustained for $180 \mathrm{~min}$ (Fig. 1B). The total amount of ERK1/2 protein was unaltered in these groups. Pretreatment with a MAPK/ERK inhibitor, U0126 $(10 \mu \mathrm{M})$, for $30 \mathrm{~min}$ with either PMA or dbcAMP markedly inhibited P-ERK1/2 levels at a concentration shown to inhibit MAPK/ERK activity in mouse Leydig and adrenal cells (Gyles et al. 2001, Manna et al. 2002a, 2006a). These results demonstrate that activation of ERK1/2 by PMA and dbcAMP involves protein phosphorylation rather than protein synthesis.

The relevance of PMA- and dbcAMP-stimulated ERK1/2 signaling on StAR expression and steroid synthesis was determined. As illustrated in Fig. 2, U0126 was capable of increasing $(P<0 \cdot 05)$ StAR protein expression by $6 \mathrm{~h}$ but not its phosphorylation (P-StAR). PMA $(10 \mathrm{nM})$ resulted in a $5 \cdot 2 \pm 1 \cdot 4$-fold elevation in StAR expression but not P-StAR,
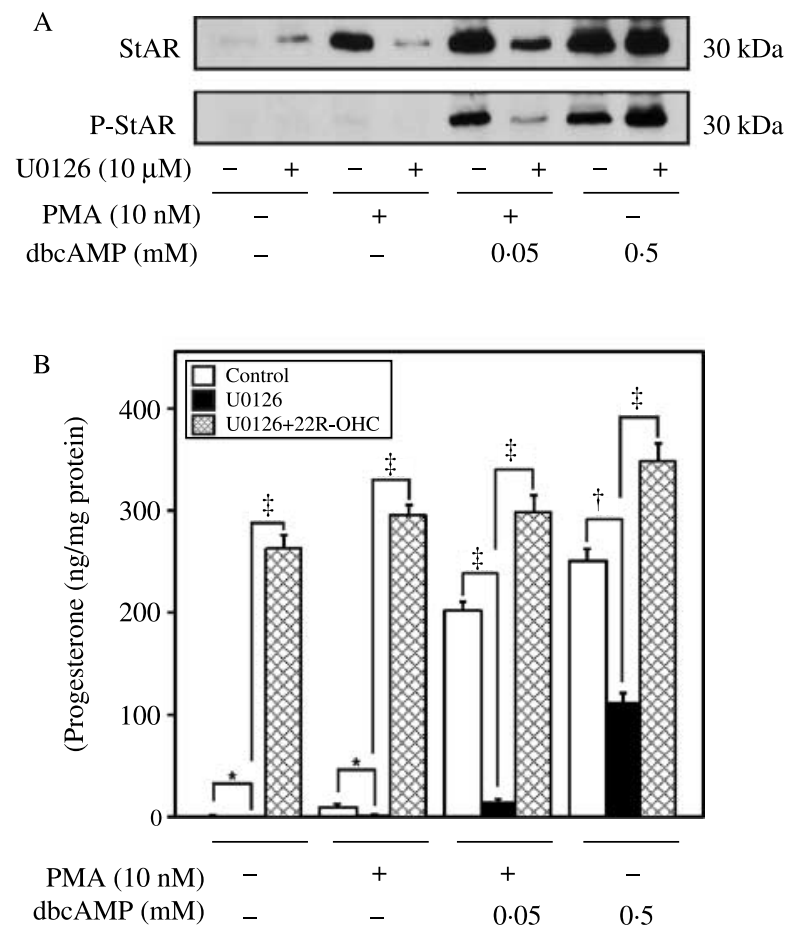

Figure 2 Role of $U 0126$ on PMA, PMA plus dbcAMP, and dbcAMP-stimulated StAR, P-StAR, and progesterone levels in MA-10 cells. Cells were pretreated with U0126 $(10 \mu \mathrm{M})$ for $30 \mathrm{~min}$ and then stimulated with PMA (10 nM), PMA plus $0.05 \mathrm{mM}$ dbcAMP or $0.5 \mathrm{mM}$ dbcAMP alone for $6 \mathrm{~h}$. Cell lysates $(22 \mu \mathrm{g}$ protein) were analyzed for StAR expression and P-StAR by western blot analysis. (A) Representative immunoblot illustrates the levels of StAR and P-StAR in different treatment groups. (B) Cells were also treated with $22 \mathrm{R}-\mathrm{OHC}(25 \mu \mathrm{M})$ in the presence or absence of $\cup 0126$, and progesterone levels in the media were determined and expressed as $\mathrm{ng} / \mathrm{mg}$ protein. Data represent the mean \pm S.E.M. of four independent experiments, ${ }^{*} P<0 \cdot 05 ;{ }^{\dagger} P<0 \cdot 01 ;{ }^{\ddagger} P<0 \cdot 001$. and a slight increase $(3 \cdot 2 \pm 0 \cdot 8$-fold $)$ in progesterone synthesis when compared with controls. Addition of $0.05 \mathrm{mM}$ dbcAMP (a dose incapable of increasing StAR expression and steroid synthesis by itself (Jo et al. 2005)) to PMA-treated cells dramatically elevated StAR, P-StAR, and progesterone to levels that are quantitatively similar to those seen with $0.5 \mathrm{mM}$ dbcAMP (Fig. 2A and B). Notably, while U0126 decreased PMA and PMA plus dbcAMP-stimulated StAR and P-StAR, it increased $(P<0 \cdot 05)$ dbcAMP-mediated responses (Fig. 2A). However, progesterone levels in response to these stimuli were significantly decreased $(P<0 \cdot 01)$ by U0126. This inhibitor also decreased basal secretion of progesterone by $44 \%$ (control, $1 \cdot 58 \pm 0.21$ vs U0126, $0 \cdot 87 \pm 0 \cdot 14 \mathrm{ng} / \mathrm{mg}$ protein). U0126 had no apparent effect on $22 R$-hydroxycholesterol (22R-OHC, $25 \mu \mathrm{M}$ )-mediated progesterone synthesis, indicating that the cytochrome $\mathrm{P} 450$ side-chain cleavage (P450scc) and $3 \beta$-hydroxysteroid

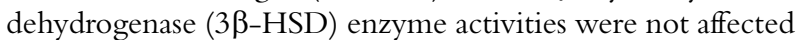
(Fig. 2B). These findings suggest that activation of ERK1/2 via PKC and PKA signaling influences StAR expression and steroid synthesis differently without affecting the activity of P450scc and 3 $\beta-H S D$.

The specificity of PMA and dbcAMP effects on ERK1/2 signaling involved in StAR expression and steroid synthesis was assessed using inhibitors of the PKC (GFX) and PKA (H89) pathways. MA-10 cells treated with PMA $(10 \mathrm{nM})$ and dbcAMP $(0.5 \mathrm{mM})$ for $30 \mathrm{~min}$ activated $(P<0.01)$ P-ERK1/2 levels, which were strongly decreased by GFX $(20 \mu \mathrm{M})$ and H89 $(20 \mu \mathrm{M})$ respectively (Fig. 3A). The concentrations of GFX and $\mathrm{H} 89$ used were based on previous studies (Jo et al. 2005, Manna et al. 2006b). Total ERK1/2 protein levels were unaltered by any of these inhibitors. The results summarized in Fig. 3B demonstrate that treatment with PMA and dbcAMP for $6 \mathrm{~h}$ resulted in $5 \cdot 4 \pm 1 \cdot 2$ - and $8 \cdot 7 \pm 1 \cdot 9$-fold increases in StAR mRNA levels over untreated cells respectively. Inclusion of GFX and H89 in these treatments decreased PMA- and dbcAMP-induced StAR mRNA expression by 68 and $74 \%$ respectively. Treatment with PMA and dbcAMP increased progesterone synthesis over basal levels by $3 \cdot 6-$ and $337 \pm 29$-fold respectively. GFX and $\mathrm{H} 89$ decreased PMA- and dbcAMP-treated progesterone synthesis by 70 and $85 \%$ respectively.

Inhibition of ERK1/2 by U0126 was found to induce StAR expression but P-StAR was undetectable. Detection of P-StAR can be seen only in the presence of $0.1 \mathrm{mM}$ dbcAMP. Both StAR and P-StAR were increased in a dose-dependent manner when U0126 and $0 \cdot 1 \mathrm{mM}$ dbcAMP were used in combination (Fig. 4A). Notably, while U0126 increased dbcAMP $(0 \cdot 1-0.5 \mathrm{mM})$-stimulated StAR and $\mathrm{P}-\mathrm{StAR}$, it decreased progesterone synthesis approximately by $50 \%$ (Fig. 4B), an observation in agreement with previous studies (Renlund et al. 2006). By contrast, U0126 markedly inhibited PMA and PMA plus 0.05 mM dbcAMP-stimulated StAR/P-StAR and progesterone levels, demonstrating U0126 had effects on StAR expression and steroid synthesis in stimulus-specific manners. 
A

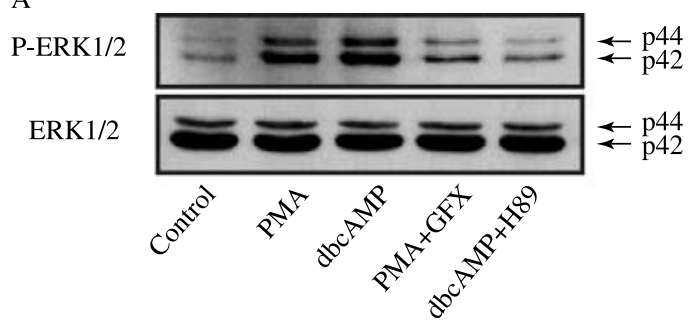

B

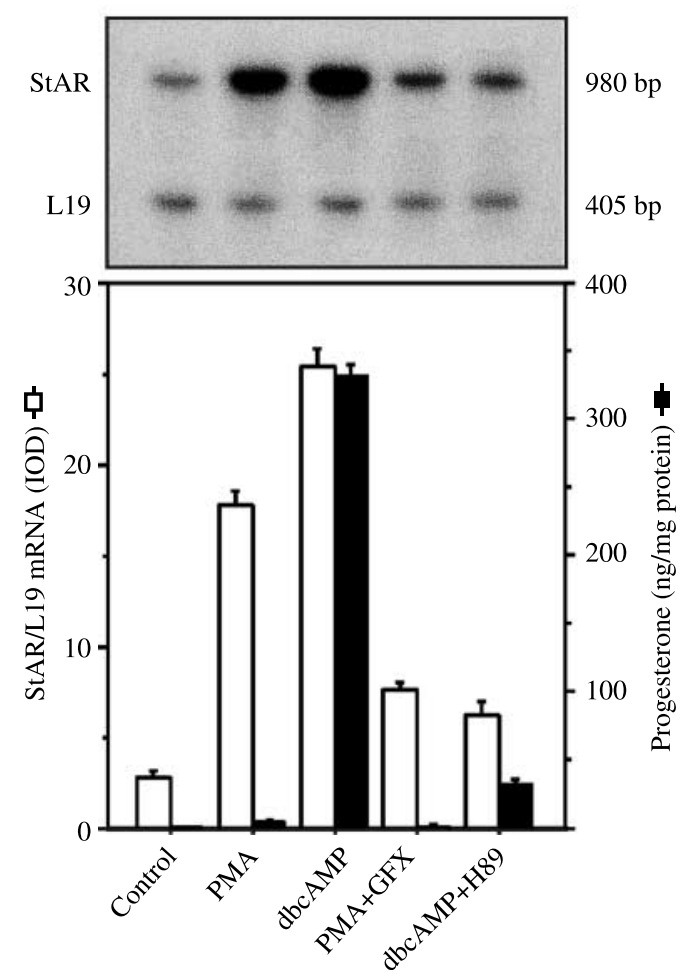

Figure 3 Role of pathway-specific inhibitors on ERK1/2 signaling and its relevance to StAR expression and progesterone synthesis. (A) MA-10 cells were pretreated with inhibitors of PKC (GFX, $20 \mu \mathrm{M})$ and PKA $(\mathrm{H} 89,20 \mu \mathrm{M})$ for $30 \mathrm{~min}$, and then treated with $10 \mathrm{nM}$ PMA and $0.5 \mathrm{mM}$ dbcAMP for an additional $30 \mathrm{~min}$. Then P-ERK1/2 and ERK1/2 in cell lysates were determined using $20 \mu \mathrm{g}$ protein. Results shown are representative of three independent experiments. (B) Cells were pretreated for $30 \mathrm{~min}$ with the inhibitors as indicated, incubated for an additional $6 \mathrm{~h}$ with PMA and dbcAMP, and subjected to RNA extraction for RT-PCR analysis of StAR and L19 mRNA expression. A representative autoradiogram shows expression of StAR mRNA by RT-PCR analysis using $2 \mu \mathrm{g}$ total RNA. Integrated optical density (IOD) values of each StAR band were quantified and normalized with the corresponding L19 bands. Progesterone levels in the media of the same treatment groups were determined ( \pm s.E.M., $n=3-4)$. Note the different scales on both sides.

Since MA-10 cells possess functional $\mathrm{LH} / \mathrm{hCG}$ receptors, the role of hCG on ERK1/2 signaling and their relevance to StAR expression and progesterone synthesis were investigated. Cells treated with hCG $(100 \mathrm{ng} / \mathrm{ml})$ for $0-180 \mathrm{~min}$ demonstrated increases in P-ERK1/2 by $3 \mathrm{~min}(P<0 \cdot 01)$, reached maximal levels between 5 and $10 \mathrm{~min}$, and slightly decreased by $180 \mathrm{~min}$ (Fig. 5A). U0126 abolished hCG-stimulated P-ERK1/2 when compared with the value at $10 \mathrm{~min}$. The amount of ERK1/2 was unchanged during this time course. Also, hCG was capable of inducing StAR expression $(4 \cdot 8 \pm 1 \cdot 5$-fold $)$ and P-StAR $(3 \cdot 5 \pm 1 \cdot 2$-fold $)$ over their respective controls. Both GFX and $\mathrm{H} 89$ decreased hCG-stimulated StAR and P-StAR by $80-95 \%$, and as a result progesterone levels were markedly attenuated (Fig. 5B). On the other hand, U0126 resulted in moderate but consistent increases $(1 \cdot 6$ - to $2 \cdot 2$-fold) in hCG-stimulated StAR and P-StAR, but significantly decreased $(P<0 \cdot 01)$ progesterone synthesis.

\section{Role of U0126 in StAR transcription and translation}

To determine whether U0126 mediates the hormonestimulated steroidogenic response at the level of transcription and/or translation, the effects of actinomycin D (Act, $4 \mu \mathrm{M})$ and cycloheximide (Chx, $5 \mu \mathrm{M})$ on dbcAMP-stimulated MA-10 cells were determined (Fig. 6). The increase in U0126-mediated StAR expression was repressed $(P<0 \cdot 05)$ by both Act and Chx, indicating U0126 induced StAR expression both at the transcriptional and translational levels (Fig. 6A). Act and Chx also diminished basal progesterone synthesis between 37 and $45 \%$. Furthermore, Act and Chx decreased $(P<0 \cdot 01)$ dbcAMP $(0.3 \mathrm{mM})$-stimulated StAR, P-StAR, and progesterone synthesis (Fig. 6B). The effect of U0126 on dbcAMPstimulated elevations in StAR and P-StAR was decreased by 86 and $65 \%$ with Act and 50 and $27 \%$ with Chx respectively. Furthermore, U0126 suppressed $(P<0 \cdot 05)$ dbcAMP-stimulated progesterone production, a response further attenuated in the presence of both Act and Chx.

\section{ERK1/2 signaling and its relevance to PMA- and $d b c A M P / h C G$-mediated expression of $D A X-1, S R-B 1$, St $A R$, and progesterone synthesis}

To obtain more insight into these mechanisms, the role of ERK1/2 signaling on PMA-, dbcAMP-, and hCG-mediated expression of DAX-1 and SR-B1 was studied and their relationship to StAR expression and progesterone synthesis was assessed. In MA-10 cells, the constitutive expression of DAX-1 was decreased to $42 \%$ by U0126 (10 $\mu \mathrm{M})$, an event that increased expression of the StAR protein. Treatment with PMA, dbcAMP, and hCG demonstrated $\approx 68$, 45, and $47 \%$ decreases in DAX-1 protein levels respectively, observations inversely correlated with StAR expression (Fig. 7A and B). Progesterone levels in response to these stimuli were inhibited by U0126 (Fig. 7C). While U0126 reversed the inhibition of PMA-treated DAX-1 expression, it further attenuated dbcAMP ( 70\%)- and hCG ( 52\%)mediated DAX-1 protein levels. 
A

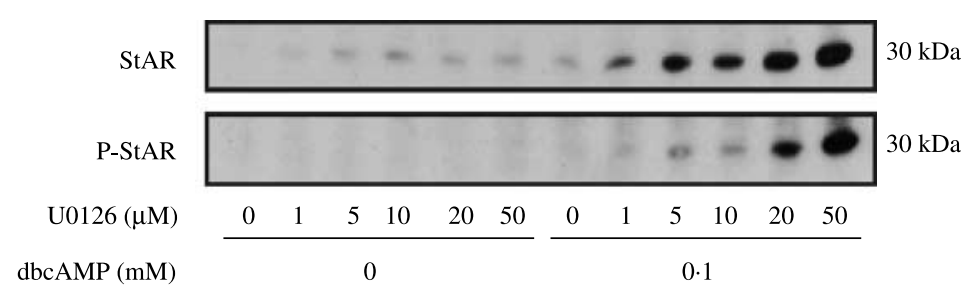

B
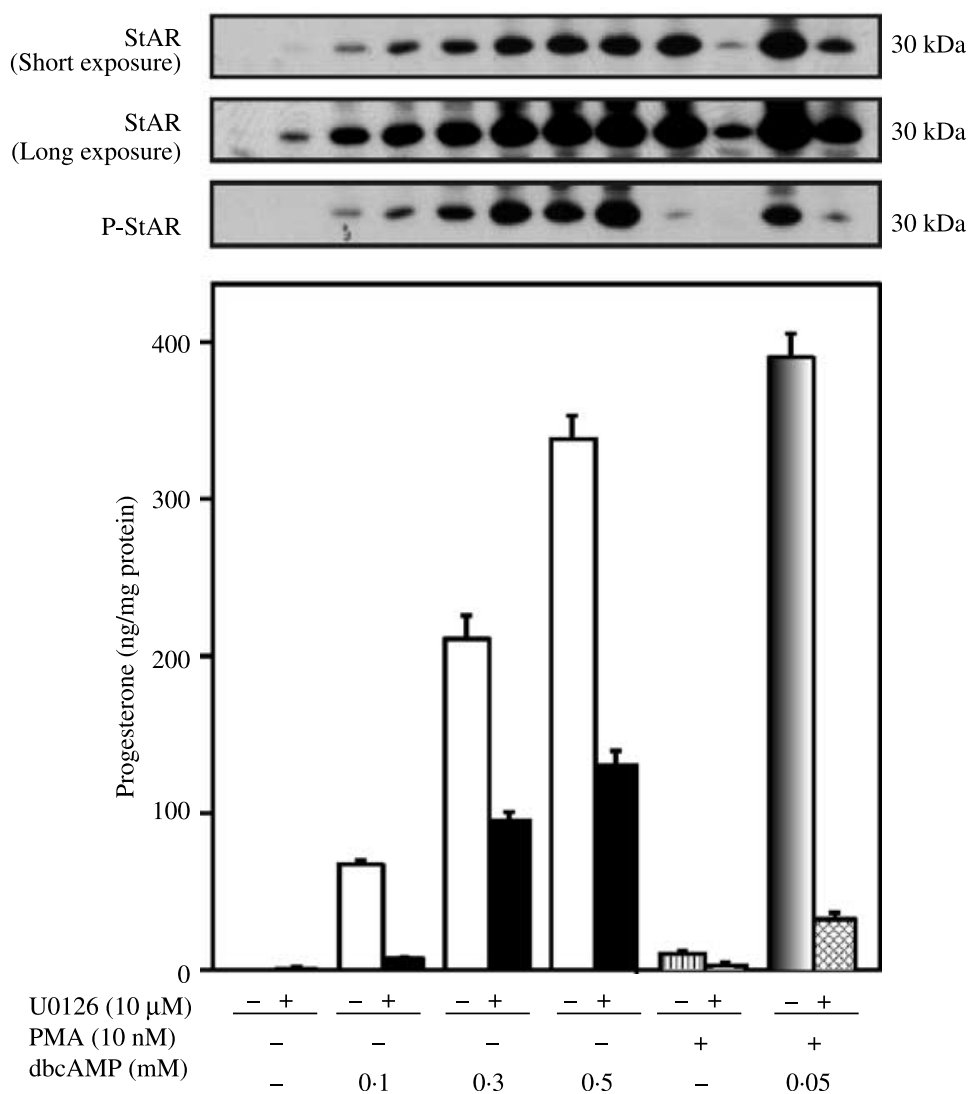

Figure 4 Effect of U0126 on PMA- and dbcAMP-stimulated StAR, P-StAR, and progesterone synthesis in MA-10 cells. (A) Cells were pretreated with increasing doses of U0126 $(0-50 \mu \mathrm{M})$ for $30 \mathrm{~min}$, incubated with or without $0 \cdot 1 \mathrm{mM}$ dbcAMP for an additional $6 \mathrm{~h}$ and StAR and P-StAR were determined by western blot analyses. (B) Cells were also treated with $10 \mathrm{nM}$ PMA, PMA plus $0.05 \mathrm{mM}$ dbcAMP, or $0 \cdot 1-0.5 \mathrm{mM}$ dbcAMP in the presence or absence of U0126 $(10 \mu \mathrm{M})$ and StAR and P-StAR were determined. Expression of StAR protein is illustrated following both short and long exposures. Representative immunoblots illustrate StAR and P-StAR in different treatment groups. The accumulation of progesterone in the same treatment groups was determined. Data represent the mean \pm s.E.M. of three independent experiments using triplicate samples.

The differential effects of U0126 on StAR expression and steroid synthesis mediated by PMA and dbcAMP/hCG prompted us to study the role of SR-B1, an HDL receptor involved in providing cholesterol for steroidogenesis (Manna et al. 2006a,b). MA-10 cells treated with PMA, dbcAMP, and hCG resulted in $5 \cdot 8 \pm 1 \cdot 6-, 18 \cdot 2 \pm 3 \cdot 6-$, and $11 \pm 2 \cdot 3$-fold increases in SR-B1 mRNA expression over basal levels respectively (Fig. 8). Addition of U0126 to these treatments repressed SR-B1 mRNA expression between 40 and 55\%, while at the same time progesterone levels were also significantly decreased $(P<0 \cdot 05)$. Thus, the suppression of progesterone synthesis by U0126 could be, at least in part, due to inhibition of SR-B1 expression resulting in an insufficient uptake of cholesterol into these cells. 
A

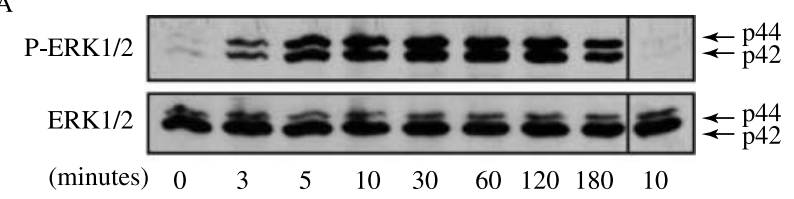

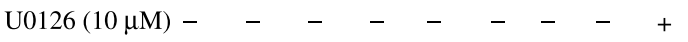

hCG $(100 \mathrm{ng} / \mathrm{ml})$

B

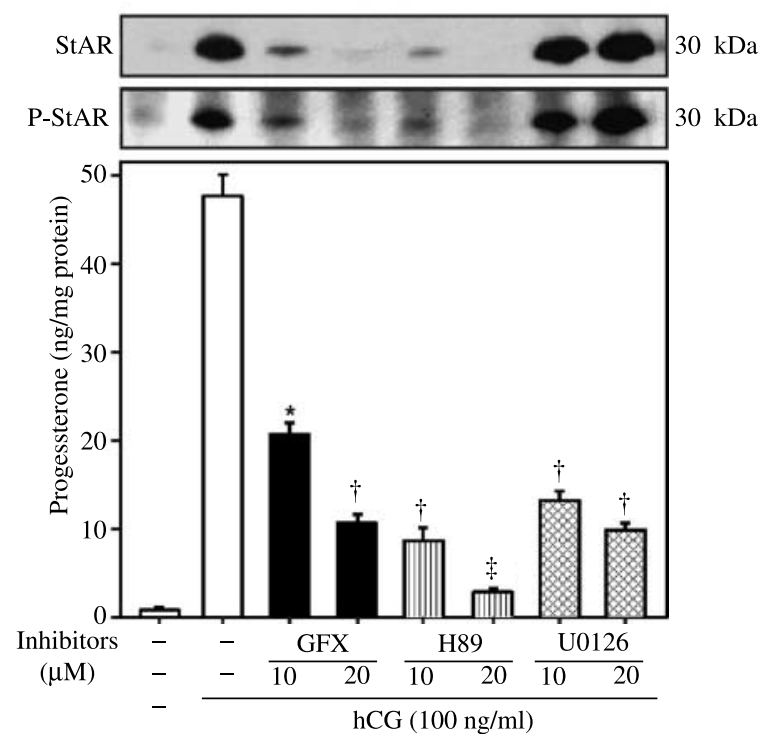

Figure 5 Effect of hCG on phosphorylation and expression of ERK1/2 and its relevance to PKC- and PKA-mediated StAR expression and steroid synthesis. (A) MA-10 cells were stimulated with $100 \mathrm{ng} / \mathrm{ml} \mathrm{hCG}$ for different time periods (0-180 $\mathrm{min})$, and cell lysates $(24 \mu \mathrm{g}$ protein) were analyzed for P-ERK $1 / 2$ and ERK $1 / 2$ by western blot analyses. (B) Cells were pretreated with two different doses $(10$ and $20 \mu \mathrm{M})$ of GFX, H89, and U0126 for 30 min and then incubated with $100 \mathrm{ng} / \mathrm{ml}$ hCG for an additional $6 \mathrm{~h}$. Cell lysates were analyzed for StAR and P-StAR. Immunoblots are representative of three independent experiments having similar results. Progesterone levels in the media of the same treatment groups were determined (B). Data represent the mean \pm S.E.M. of three independent experiments. ${ }^{*} P<0 \cdot 05 ;{ }^{\dagger} P<0 \cdot 01 ;{ }^{\ddagger} P<0 \cdot 001$ vs hCG response.

\section{Discussion}

The MAPK/ERK signaling cascade has been demonstrated to regulate StAR expression and steroid biosynthesis. However, several contradictions to this observation have been reported in different steroidogenic tissues (Gyles et al. 2001, Seger et al. 2001, Dewi et al. 2002, Seto-Young et al. 2003, Martinelle et al. 2004, Martinat et al. 2005, Tajima et al. 2005, Manna et al. 2006b). For example, activation of ERK1/2 by hCG has been shown to increase StAR transcription and testosterone production in immature rat Leydig cells (Martinelle et al. 2004). Conversely, inhibition of ERK1/2 enhances LH- and FSH-mediated StAR expression and steroid synthesis in rat granulosa cells (Seger et al. 2001, Amsterdam et al. 2003).
In rat primary and mLTC-1 mouse Leydig tumor cells, ERK1/2 inhibition was shown to increase LH-, insulin-like growth factor-I-, and transforming growth factor- $\boldsymbol{\alpha}$-mediated StAR expression but decreased steroid synthesis (Martinat et al. 2005, Manna et al. 2006a,b). Also, ERK1/2 signaling resulted in differential effects on LH-induced StAR and CYP17 levels, producing an increase in progesterone but a decrease in androsterone synthesis in bovine theca cells (Tajima et al. 2005). In granulosa lutein cells, while inhibition of ERK1/2 had no effect on LH/hCG-induced steroidogenesis, it decreased $(\mathrm{Bu})_{2} \mathrm{CAMP}-$, cholera toxin-, and forskolin-stimulated progesterone levels (Dewi et al. 2002). The present studies extend these observations by elucidating the molecular events in which the ERK1/2 cascade (in correlation with PKA and PKC signaling) acts to drive StAR expression and, thus, steroid biosynthesis in mouse Leydig cells.

Our findings demonstrate that both the PKC (activated by PMA) and PKA (activated by dbcAMP/hCG) signaling pathways are capable of rapidly phosphorylating ERK1/2. Selective inhibition of these pathways using specific inhibitors markedly repressed ERK1/2 phosphorylation and had a variety of effects on StAR expression and steroidogenesis. In previous studies, we examined the effect of several doses of these inhibitors and found them to have no adverse effects on cell viability or cellular DNA synthesis when compared with control Leydig cells (Manna et al. 2001, 2002a, Rao et al. 2003, Jo et al. 2005, Manna et al. 2006a). In addition, these inhibitors have also been widely used for blocking relevant signaling pathways in other steroidogenic cells (Gyles et al. 2001, Seger et al. 2001, Martinelle et al. 2004). Interestingly, inhibition of ERK1/2 by U0126 decreased PMA-stimulated StAR expression but increased dbcAMP/hCG responsiveness. However, progesterone levels were decreased by these treatments. The decrease in progesterone synthesis was not associated with inhibition of P450scc and/or $3 \beta-\mathrm{HSD}$, as U0126 had no effect on 22R-OHC-mediated progesterone production. Consistent with this, ERK1/2 inhibition has been demonstrated to decrease forskolin-stimulated pregnenolone synthesis in MA-10 cells, but in those studies the expression of the StAR protein was not determined (Gyles et al. 2001). In human LH receptor expressing MA-10 cells, hCG was able to increase the PKA-mediated phosphorylation of Ras and ERK1/2 (Hirakawa \& Ascoli 2003). Also, the effect of hCG on P-ERK1/2 was diminished by the inhibition of PKC and PKA responsiveness in immature rat Leydig cells (Martinelle et al. 2004). These observations indicate the complexity of the role of the ERK1/2 signaling cascade, which could be dependent on receptor-effector coupling and might involve signaling crosstalk and/or the involvement of additional factor(s) in the regulation of the steroidogenic response.

The regulation of StAR expression and steroidogenesis involves multiple second messenger systems including the PKA (Balasubramanian et al. 1997, Manna et al. 1999b, Sekar et al. 2000, Gyles et al. 2001, Martinat et al. 2005, Manna et al. 2006a) and PKC (Fiedler et al. 1999, Jo et al. 2005, Manna 
A

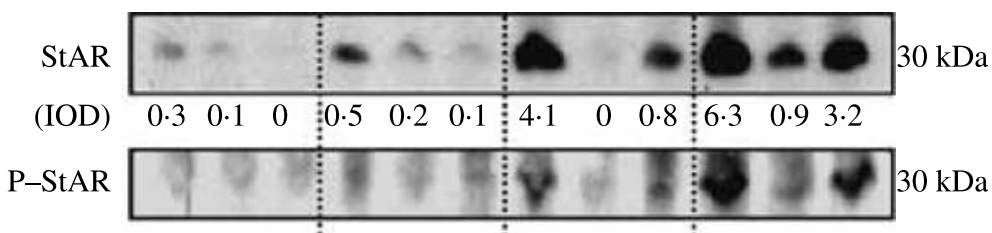

B

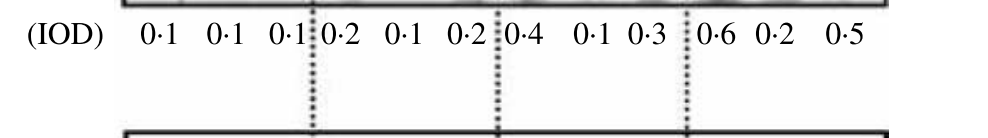

$$
\begin{gathered}
\operatorname{U0126}(10 \mu \mathrm{M}) \\
\operatorname{dbcAMP}(0.3 \mathrm{mM})
\end{gathered}
$$

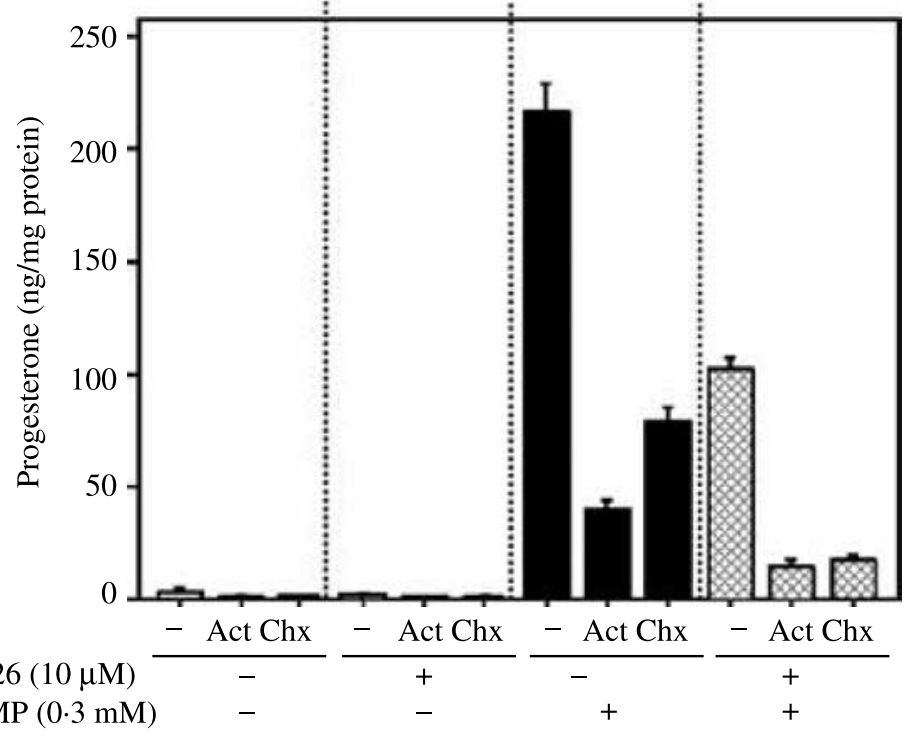

Figure 6 Role of U0126 on StAR transcription/translation and progesterone production in MA-10 cells. (A) Cells were pretreated with either actinomycin D (Act, $4 \mu \mathrm{M})$ or cycloheximide (Chx, $5 \mu \mathrm{M})$ for $30 \mathrm{~min}$, incubated with or without U0126 (10 $\mu \mathrm{M})$ for a further $30 \mathrm{~min}$, and then stimulated for an additional $6 \mathrm{~h}$ in the presence or absence of $0.3 \mathrm{mM}$ dbcAMP. Cell lysates $(22 \mu \mathrm{g}$ protein) were analyzed for StAR and P-StAR by western blot analyses. Similar results were obtained from three independent experiments, and integrated optical density (IOD) values from representative immunoblots are given. (B) Accumulation of progesterone in the media was determined. Data represent the mean \pm s.E.M. of three independent experiments.

et al. 2006a,b, Renlund et al. 2006) pathways. It is noted, however, that the effect of PKC signaling on steroid synthesis is far smaller than that of PKA signaling, usually being $1 \%$ of that seen with PKA activation, and the inability of PKC to phosphorylate StAR has been demonstrated to be a critical event for this dramatic difference (Jo et al. 2005, Manna et al. 2006a). Our present data corroborate previous findings which indicated that both the PKA and PKC pathways are involved in regulating StAR expression and steroidogenesis (Jo et al. 2005, Martinat et al. 2005, Manna et al. 2006a,b), and demonstrated that inhibition of ERK1/2 by U0126 elevated StAR protein expression but not its phosphorylation. Activation of PKC by PMA markedly increased the expression of the StAR protein but not P-StAR, thus producing inactive StAR and resulting in only a modest increase in progesterone synthesis. Increasing the PKA activity with a low dose of dbcAMP (one that is ineffective in increasing the steroidogenic response) in PMA-treated cells dramatically enhanced P-StAR and progesterone levels. While ERK1/2 inhibition resulted in decreases in PMA and PMA plus dbcAMP-stimulated StAR/P-StAR and progesterone levels, it produced increases in dbcAMP/ hCG-stimulated StAR expression and P-StAR, but diminished progesterone synthesis. These results are in support of the previous findings demonstrating that ERK1/2 inhibition increased interleukin-1 $\alpha$ (IL-1 $\alpha$ )-stimulated StAR and P-StAR but decreased androgen synthesis in rat Leydig cells (Renlund et al. 2006). Thus, it appears that ERK1/2 signaling plays a discrete role in StAR expression and steroid synthesis in pathway- and/or stimulus-specific manners in mouse Leydig cells.

In view of our present findings, it appears that the transcription factor DAX-1, which plays an important role in regulating StAR expression through the PKA pathway, is also regulated by PKC signaling. In addition to its role in the development of the adrenal and gonads, DAX-1 has been demonstrated to negatively regulate StAR expression and steroid synthesis both in Leydig and adrenal cells (Zazopoulos et al. 1997, Lalli et al. 1998, Manna et al. 1999a,b, Jo \& Stocco 2004). In this study, we observed that inhibition of ERK1/2 


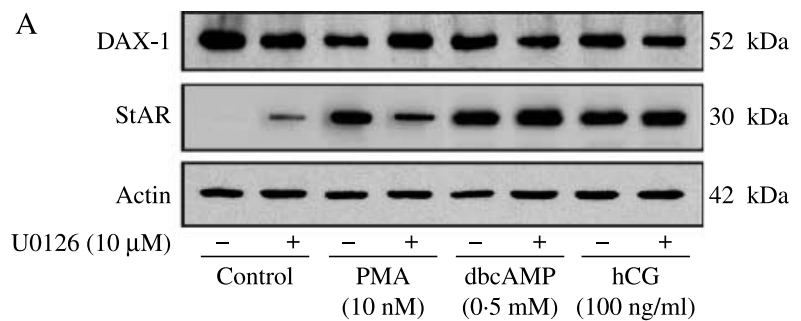

B

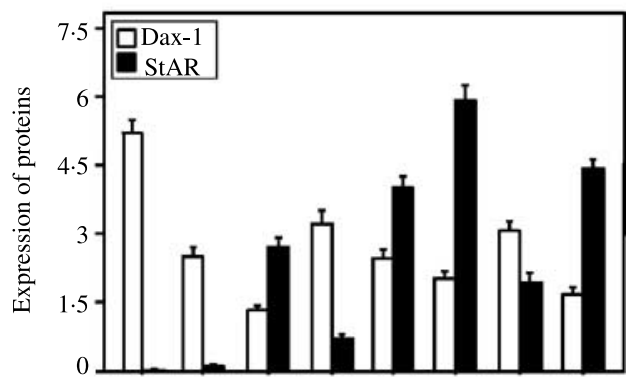

C

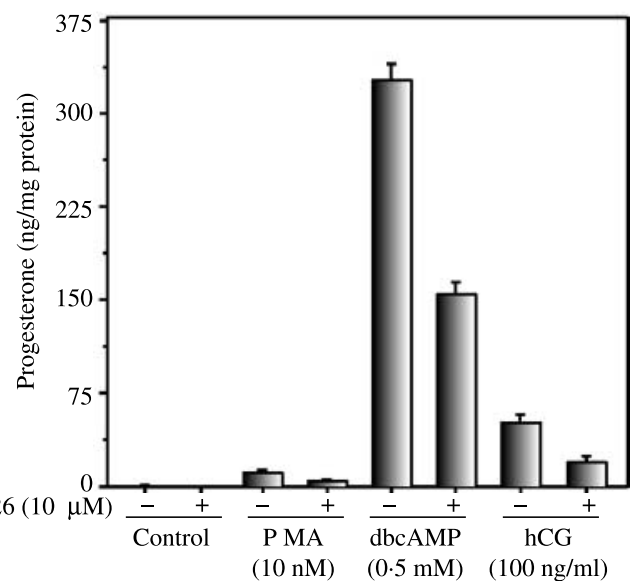

Figure 7 Role of U0126 on PMA-, dbcAMP-, and hCG-stimulated DAX-1 expression and its relevance to StAR expression and steroid synthesis. MA-10 cells were pretreated with U0126 $(10 \mu \mathrm{M})$ for $30 \mathrm{~min}$ and then incubated with $10 \mathrm{nM}$ PMA, $0.5 \mathrm{mM}$ dbcAMP, and $100 \mathrm{ng} / \mathrm{ml} \mathrm{hCG}$ for an additional $6 \mathrm{~h}$. Cell lysates (23-25 $\mu \mathrm{g}$ protein) were analyzed for DAX-1 and StAR protein expression by western blot analyses. (A) Representative immunoblots illustrate expression of DAX-1 and StAR proteins in different treatment groups.

Expression of actin in different groups was determined as a loading control (lower panel). (B) IOD values of DAX-1 and StAR bands were quantified. (C) Accumulation of progesterone in the media of the same treatment groups was determined. Data represent the mean \pm S.E.M. of three independent experiments.

was associated with a decrease in DAX-1 expression. While PMA, dbcAMP, and hCG increased StAR expression and progesterone synthesis, they inhibited expression of the DAX-1 levels. In support of this mechanism, an inverse relationship between DAX-1 and StAR expression has been reported in different steroidogenic cells (Tamai et al. 1996, Osman et al. 2002, Manna et al. 2006a,b). Furthermore, the inhibitory effect of PMA on DAX-1 expression could be reversed by U0126, which, in contrast, further diminished dbcAMP/hCG-mediated DAX-1 levels. Therefore, the

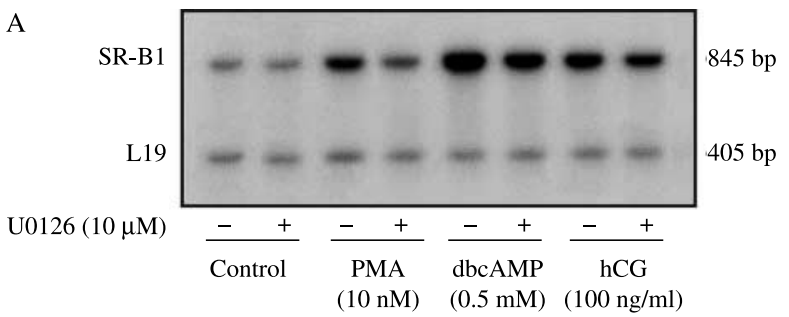

B

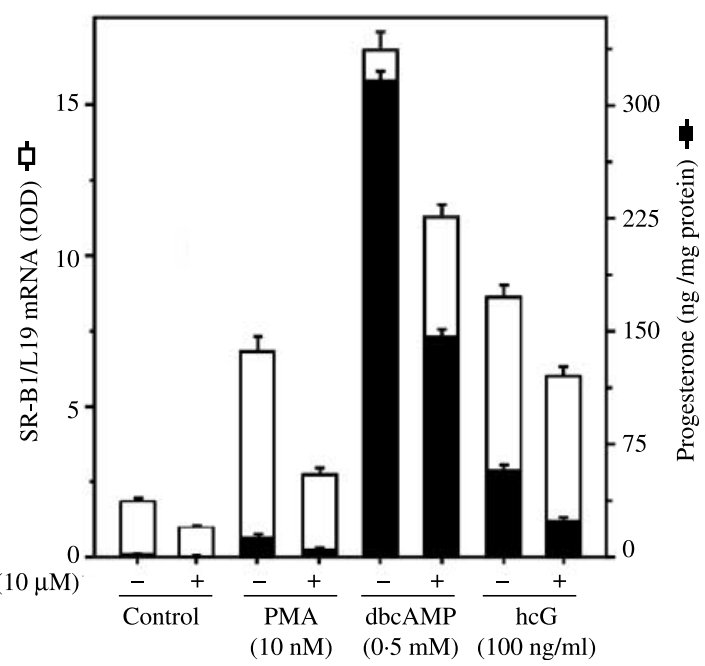

Figure 8 Effect of U0126 on PMA-, dbcAMP-, and hCG-stimulated SR-B1 mRNA expression and progesterone synthesis in MA-10 cells. (A) Cells were pretreated with $\cup 0126$ for $30 \mathrm{~min}$ and then incubated with $10 \mathrm{nM}$ PMA, $0.5 \mathrm{mM}$ dbcAMP, and $100 \mathrm{ng} / \mathrm{ml} \mathrm{hCG}$ for an additional $6 \mathrm{~h}$, and the steady-state levels of SR-B1 mRNA were determined by RT-PCR analysis using $2 \mu \mathrm{g}$ total RNA. A representative autoradiogram illustrates SR-B1 mRNA expression in different treatment groups. (B) Integrated optical density (IOD) values for each SR-B1 band were determined and normalized with the corresponding L19 bands. The accumulation of progesterone in the media following the same treatments was determined. Data represent the mean \pm S.E.M. of four independent experiments. Note the different scales on both sides.

differential effects of U0126 on PKC- and PKA-mediated StAR expression might be explained, at least in part, by alterations in DAX-1 expression.

The present results also demonstrate the importance of $\mathrm{SR}-\mathrm{B} 1$ in regulating steroid biosynthesis. SR-B1 is involved in providing cholesterol substrate for steroidogenesis in steroidogenic tissues. In MA-10 cells, we observed relatively low levels of SR-B1 mRNA by RT-PCR analysis. PMA and $\mathrm{dbcAMP} / \mathrm{hCG}$ treatments were found to markedly increase SR-B1 mRNA expression, an event decreased by ERK1/2 inhibition, and are in agreement with our recent findings in mLTC1 cells (Manna et al. 2006a,b). Previous studies have also documented that the expression of SR-B1 increases with $\mathrm{hCG} / \mathrm{ACTH}$ and decreases with dexamethasone and is coordinately regulated with steroid synthesis in Leydig and adrenocortical cells (Landschulz et al. 1996, Rigotti 
et al. 1996, Sun et al. 1999). In addition, the direct involvement of ACTH on the HDL-mediated cholesterol influx, the utilization of this cholesterol for steroid synthesis, and the induction of SR-B1 expression have been demonstrated in the adrenal gland (Rigotti et al. 1996). However, it has been shown that HDL binding to SR-B1 stimulates the ERK1/2 pathway following Ras activation (Grewal et al. 2003). Overall, it is conceivable that the decrease in progesterone synthesis in MA-10 cells caused by U0126 (even with elevated StAR) could be a result of a decreased uptake of cholesterol into cells due to the repression of SR-B1. Previously, U0126 has been shown to suppress IL- $1 \alpha-$ stimulated androgen production by dissipating the mitochondrial electrochemical potential in immature rat Leydig cells (Renlund et al. 2006). Hence, we cannot exclude the possibility that U0126 might inhibit PMA- and dbcAMP/ hCG-stimulated progesterone production by affecting the integrity of the mitochondria.

Taken together, these findings provide insight into the mechanisms of ERK1/2 signaling in regulating PKC- and PKA-mediated StAR expression and steroidogenesis in mouse Leydig cells and illustrate the involvement of DAX-1 and SR-B1 in these processes. Thus, multiple and complex intracellular events appear to be involved in crosstalk among the different pathways and may function in regulating the steroidogenic response in Leydig cells. The exploration of the MAPK/ERK1/2 signaling pathway may help in understanding the mitogenic potential of a variety of hormones and growth factors in other steroidogenic cells.

\section{Acknowledgements}

We thank Dr W L Miller, Dr S R King, and Dr P SassoneCorsi for the generous gifts of valuable reagents. This investigation was supported in part by the NIH grant HD-17481 and the R A Welch Foundation Grant B1-0028. The authors declare that there is no conflict of interest that would prejudice the impartiality of this scientific work.

\section{References}

Amsterdam A, Tajima K, Frajese V \& Seger R 2003 Analysis of signal transduction stimulated by gonadotropins in granulosa cells. Molecular and Cellular Endocrinology 202 77-80.

Arakane F, King SR, Du Y, Kallen CB, Walsh LP, Watari H, Stocco DM \& Strauss JF III 1997 Phosphorylation of steroidogenic acute regulatory protein (StAR) modulates its steroidogenic activity. Journal of Biological Chemistry 272 32656-32662.

Ascoli M 1981 Characterization of several clonal lines of cultured Leydig tumor cells: gonadotropin receptors and steroidogenic responses. Endocrinology 108 88-95.

Ascoli M, Fanelli F \& Segaloff DL 2002 The lutropin/choriogonadotropin receptor, a 2002 perspective. Endocrine Reviews 23 141-174.

Azhar S, Nomoto A, Leers-Sucheta S \& Reaven E 1998 Simultaneous induction of an HDL receptor protein (SR-B1) and the selective uptake of HDL-cholesteryl esters in a physiologically relevant steroidogenic cell model. Journal of Lipid Research 39 1616-1628.
Balasubramanian K, Lavoie HA, Garmey JC, Stocco DM \& Veldhuis JD 1997 Regulation of porcine granulosa cell steroidogenic acute regulatory protein (StAR) by insulin-like growth factor I: synergism with follicle-stimulating hormone or protein kinase A agonist. Endocrinology 138 433-439.

Bose HS, Whittal RM, Baldwin MA \& Miller WL 1999 The active form of the steroidogenic acute regulatory protein, StAR, appears to be a molten globule. PNAS 96 7250-7255.

Caron KM, Soo SC, Wetsel WC, Stocco DM, Clark BJ \& Parker KL 1997 Targeted disruption of the mouse gene encoding steroidogenic acute regulatory protein provides insights into congenital lipoid adrenal hyperplasia. PNAS 94 11540-11545.

Clark BJ, Wells J, King SR \& Stocco DM 1994 The purification, cloning, and expression of a novel luteinizing hormone-induced mitochondrial protein in MA-10 mouse Leydig tumor cells. Characterization of the steroidogenic acute regulatory protein (StAR). Journal of Biological Chemistry 269 28314-28322.

Clark BJ, Combs R, Hales KH, Hales DB \& Stocco DM 1997 Inhibition of transcription affects synthesis of steroidogenic acute regulatory protein and steroidogenesis in MA-10 mouse Leydig tumor cells. Endocrinology 138 4893-4901.

Cooke BA, Choi MC, Dirami G, Lopez-Ruiz MP \& West AP 1992 Control of steroidogenesis in Leydig cells. Journal of Steroid Biochemistry and Molecular Biology 43 445-449.

Dewi DA, Abayasekara DR \& Wheeler-Jones CP 2002 Requirement for ERK1/2 activation in the regulation of progesterone production in human granulosa-lutein cells is stimulus specific. Endocrinology 143 $877-888$.

Fidge NH 1999 High density lipoprotein receptors, binding proteins, and ligands. Journal of Lipid Research 40 187-201.

Fiedler EP, Plouffe L Jr, Hales DB, Hales KH \& Khan I 1999 Prostaglandin $\mathrm{F} 2 \alpha$ induces a rapid decline in progesterone production and steroidogenic acute regulatory protein expression in isolated rat corpus luteum without altering messenger ribonucleic acid expression. Biology of Reproduction $\mathbf{6 1}$ 643-650.

Grewal T, de Diego I, Kirchhoff MF, Tebar F, Heeren J, Rinninger F \& Enrich C 2003 High density lipoprotein-induced signaling of the MAPK pathway involves scavenger receptor type B1-mediated activation of Ras. Journal of Biological Chemistry 278 16478-16481.

Gyles SL, Burns CJ, Whitehouse BJ, Sugden D, Marsh PJ, Persaud SJ \& Jones PM 2001 ERKs regulate cyclic AMP-induced steroid synthesis through transcription of the steroidogenic acute regulatory $(S t A R)$ gene. Journal of Biological Chemistry 276 34888-34895.

Hasegawa T, Zhao L, Caron KM, Majdic G, Suzuki T, Shizawa S, Sasano H \& Parker KL 2000 Developmental roles of the steroidogenic acute regulatory protein (StAR) as revealed by StAR knockout mice. Molecular Endocrinology 14 1462-1471.

Hirakawa T \& Ascoli M 2003 The lutropin/choriogonadotropin receptorinduced phosphorylation of the extracellular signal-regulated kinases in Leydig cells is mediated by a protein kinase A-dependent activation of ras. Molecular Endocrinology 17 2189-2200.

Jeffs B, Meeks JJ, Ito M, Martinson FA, Matzuk MM, Jameson JL \& Russell LD 2001 Blockage of the rete testis and efferent ductules by ectopic Sertoli and Leydig cells causes infertility in Dax1-deficient male mice. Endocrinology 142 4486-4495.

Ji Y, Jian B, Wang N, Sun Y, Moya ML, Phillips MC, Rothblat GH, Swaney JB \& Tall AR 1997 Scavenger receptor B1 promotes high density lipoproteinmediated cellular cholesterol efflux. Journal of Biological Chemistry 272 20982-20985.

Jo Y \& Stocco DM 2004 Regulation of steroidogenesis and steroidogenic acute regulatory protein in $\mathrm{R} 2 \mathrm{C}$ cells by DAX-1 (dosage-sensitive sex reversal, adrenal hypoplasia congenita, critical region on the $\mathrm{X}$ chromosome, gene-1). Endocrinology 145 5629-5637.

Jo Y, King SR, Khan SA \& Stocco DM 2005 Involvement of protein kinase C and cyclic adenosine $3^{\prime}, 5^{\prime}$-monophosphate-dependent kinase in steroidogenic acute regulatory protein expression and steroid biosynthesis in Leydig cells. Biology of Reproduction 73 244-255.

Lalli E, Melner MH \& Stocco DM 1998 Sassone-Corsi P DAX-1 blocks steroid production at multiple levels. Endocrinology 139 4237-4243. 
Landschulz KT, Pathak RK, Rigotti A, Krieger M \& Hobbs HH 1996 Regulation of scavenger receptor, class $\mathrm{B}$, type $\mathrm{I}$, a high density lipoprotein receptor, in liver and steroidogenic tissues of the rat. Journal of Clinical Investigation 98 984-995.

Le T \& Schimmer BP 2001 The regulation of MAPKs in Y1 mouse adrenocortical tumor cells. Endocrinology 142 4282-4287.

Lewis TS, Shapiro PS \& Ahn NG 1998 Signal transduction through MAP kinase cascades. Advances in Cancer Research 74 49-139.

Lin D, Sugawara T, Strauss JF III, Clark BJ, Stocco DM, Saenger P, Rogol A \& Miller WL 1995 Role of steroidogenic acute regulatory protein in adrenal and gonadal steroidogenesis. Science 267 1828-1831.

Manna PR, Tena-Sempere M \& Huhtaniemi IT 1999a Molecular mechanisms of thyroid hormone-stimulated steroidogenesis in mouse Leydig tumor cells. Involvement of the steroidogenic acute regulatory (StAR) protein. Journal of Biological Chemistry 274 5909-5918.

Manna PR, Pakarinen P, El-Hefnawy T \& Huhtaniemi IT 1999b Functional assessment of the calcium messenger system in cultured mouse Leydig tumor cells: regulation of human chorionic gonadotropin-induced expression of the steroidogenic acute regulatory protein. Endocrinology $\mathbf{1 4 0}$ 1739-1751.

Manna PR, Kero J, Tena-Sempere M, Pakarinen P, Stocco DM \& Huhtaniemi IT 2001 Assessment of mechanisms of thyroid hormone action in mouse Leydig cells: regulation of the steroidogenic acute regulatory protein, steroidogenesis, and luteinizing hormone receptor function. Endocrinology 142 319-331.

Manna PR, Huhtaniemi IT, Wang XJ, Eubank DW \& Stocco DM 2002a Mechanisms of epidermal growth factor signaling: regulation of steroid biosynthesis and the steroidogenic acute regulatory protein in mouse Leydig tumor cells. Biology of Reproduction 67 1393-1404.

Manna PR, Dyson MT, Eubank DW, Clark BJ, Lalli E, Sassone-Corsi P, Zeleznik AJ \& Stocco DM $2002 b$ Regulation of steroidogenesis and the steroidogenic acute regulatory protein by a member of the cAMP responseelement binding protein family. Molecular Endocrinology 16 184-199.

Manna PR, Eubank DW \& Stocco DM 2004a Assessment of the role of activator protein-1 on transcription of the mouse steroidogenic acute regulatory protein gene. Molecular Endocrinology 18 558-573.

Manna PR, Huhtaniemi IT \& Stocco DM $2004 b$ Detection of hCG responsive expression of the steroidogenic acute regulatory protein in mouse Leydig cells. Biological Procedure Online 6 683-693.

Manna PR, Chandrala SP, Jo Y \& Stocco DM 2006 a cAMP-independent signaling regulates steroidogenesis in mouse Leydig cells in the absence of StAR phosphorylation. Journal of Molecular Endocrinology 37 81-95.

Manna PR, Chandrala SP, King SR, Jo Y, Counis R, Huhtaniemi IT \& Stocco DM $2006 b$ Molecular mechanisms of insulin-like growth factor-I mediated regulation of the steroidogenic acute regulatory protein in mouse Leydig cells. Molecular Endocrinology 20 362-378.

Martinat N, Crepieux P, Reiter E \& Guillou F 2005 Extracellular signal-regulated kinases (ERK) 1, 2 are required for luteinizing hormone (LH)-induced steroidogenesis in primary Leydig cells and control steroidogenic acute regulatory (StAR) expression. Reproduction, Nutrition, Development 45 101-108.

Martinelle N, Holst M, Soder O \& Svechnikov K 2004 Extracellular signal-regulated kinases are involved in the acute activation of steroidogenesis in immature rat Leydig cells by human chorionic gonadotropin. Endocrinology 145 4629-4634.

Meeks JJ, Crawford SE, Russell TA, Morahashi K, Weiss J \& Jameson JL 2003a Dax1 regulates testis cord organization during gonadal differentiation. Development 130 1029-1036.

Meeks JJ, Russell TA, Jeefs B, Huhtaniemi I, Weiss J \& Jameson JL $2003 b$ Leydig cell-specific expression of DAX1 improves fertility of the Dax1-deficient mouse. Biology of Reproduction 69 1154-1160.

Niakan KK \& McCabe ER 2005 DAX1 origin, function, and novel role. Biochemical and Molecular Medicine 86 70-83.

Osman H, Murigande C, Nadakal A \& Capponi AM 2002 Repression of DAX-1 and induction of SF-1 expression. Two mechanisms contributing to the activation of aldosterone biosynthesis in adrenal glomerulosa cells. Journal of Biological Chemistry 277 41259-41267.
Rao RM, Jo Y, Leers-Sucheta S, Bose HS, Miller WL, Azhar S \& Stocco DM 2003 Differential regulation of steroid hormone biosynthesis in R2C and MA-10 Leydig tumor cells: role of SR-B1-mediated selective cholesteryl ester transport. Biology of Reproduction 68 114-121.

Renlund N, Jo Y, Svechnikova I, Holst M, Stocco DM, Soder O \& Svechnikov K 2006 Induction of steroidogenesis in immature rat Leydig cells by interleukin-1alpha is dependent on extracellular signal-regulated kinases. Journal of Molecular Endocrinology 36 327-336.

Rigotti A, Edelman ER, Seifert P, Iqbal SN, DeMattos RB, Temel RE, Krieger M \& Williams DL 1996 Regulation by adrenocorticotropic hormone of the in vivo expression of scavenger receptor class B type I (SR-B1), a high density lipoprotein receptor, in steroidogenic cells of the murine adrenal gland. Journal of Biological Chemistry 271 33545-33549.

Rommerts FFG, King SR \& Span PN 2001 Implications of progesterone metabolism in MA-10 cells for accurate measurement of the rate of steroidogenesis. Endocrinology 142 5236-5242.

Saez JM 1994 Leydig cells: endocrine, paracrine, and autocrine regulation. Endocrine Reviews 15 574-626.

Seger R \& Krebs EG 1995 The MAPK signaling cascade. FASEB Journal $9726-735$.

Seger R, Hanoch T, Rosenberg R, Dantes A, Merz WE, Strauss JF III \& Amsterdam A 2001 The ERK signaling cascade inhibits gonadotropin-stimulated steroidogenesis. Journal of Biological Chemistry 276 13957-13964

Sekar N, Lavoie HA \& Veldhuis JD 2000 Concerted regulation of steroidogenic acute regulatory gene expression by luteinizing hormone and insulin (or insulin-like growth factor I) in primary cultures of porcine granulosa-luteal cells. Endocrinology 141 3983-3992.

Seto-Young D, Zajac J, Liu HC, Rosenwaks Z \& Poretsky L 2003 The role of mitogen-activated protein kinase in insulin and insulin-like growth factor I (IGF-I) signaling cascades for progesterone and IGF-binding protein-1 production in human granulosa cells. Journal of Clinical Endocrinology and Metabolism 88 3385-3391.

Stocco DM \& Clark BJ 1996 Regulation of the acute production of steroids in steroidogenic cells. Endocrine Reviews 17 221-244.

Stocco DM, Wang X, Jo Y \& Manna PR 2005 Multiple signaling pathways regulating steroidogenesis and steroidogenic acute regulatory protein expression: more complicated than we thought. Molecular Endocrinology 19 2647-2659.

Sun Y, Wang N \& Tall AR 1999 Regulation fo adrenal scavenger receptor-B1 expression by ACTH and cellular cholesterol pools. Journal of Lipid Research 40 1799-1805.

Tajima K, Dantes A, Yao Z, Sorokina K, Kotsuji F, Seger R \& Amsterdam A 2003 Down-regulation of steroidogenic response to gonadotropins in human and rat preovulatory granulosa cells involves mitogen-activated protein kinase activation and modulation of DAX-1 and steroidogenic factor-1. Journal of Clinical Endocrinology and Metabolism 88 2288-2299.

Tajima K, Yoshii K, Fukuda S, Orisaka M, Miyamoto K, Amsterdam A \& Kotsuji F 2005 Luteinizing hormone-induced extracellular-signal regulated kinase activation differently modulates progesterone and androstenedione production in bovine theca cells. Endocrinology 146 2903-2910.

Tamai KT, Monaco L, Alastalo TP, Lalli E, Parvinen M \& Sassone-Corsi P 1996 Hormonal and developmental regulation of DAX-1 expression in Sertoli cells. Molecular Endocrinology 10 1561-1569.

Yu RN, Ito M, Saunders TL, Camper SA \& Jameson JL 1998 Role of ACTH in gonadal development and ganetogenesis. Nature Genetics 20 353-357.

Zazopoulos E, Lalli E, Stocco DM \& Sassone-Corsi P 1997 DNA binding and transcriptional repression by DAX-1 blocks steroidogenesis. Nature 390 $311-315$.

\section{Received in final form 11 January 2007 \\ Accepted 15 January 2007}

Made available online as an Accepted Preprint 25 January 2007 